low blood glucose level, to maintain the normal blood glucose level in the body [Fig No. 1].

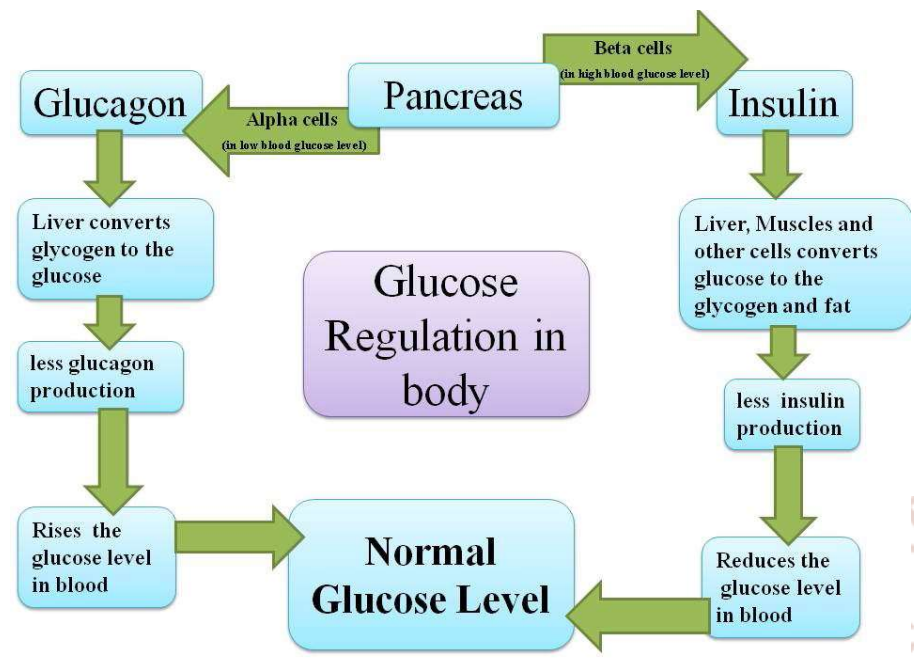

Fig No. 1 Regulation of blood glucose level in body

\section{Diabetes Mellitus:}

Diabetes is a state of improperly regulated homeostasis of carbohydrate and lipid metabolism is one of the major health problem in recent time. It is characterised by increased blood glucose level (Hyperglycaemia), glycosuria, hyperlipidaemia, negative nitrogen balance and sometimes ketonaemia [1]. It is often connected with the development of micro and macro vascular diseases which include a long term damage, dysfunction and failure of various organs especially the eye, nerves, heart, kidney and blood vessels. Global increase in diabetes may be related to increased level of obesity. Diabetes can leads to serious medical complications- blindness from retinopathy, renal failure, gangrene and limb amputation, cardiovascular disease and premature death [2]. Diabetes are of two types first, type $1 /$ insulin-dependent diabetes mellitus (IDDM) in which there is a beta-cell destruction in pancreatic islets cause low or very low insulin level in circulation and second, type 2/Noninsulin dependent diabetes mellitus (NIDDM) in which there is reduced sensitivity of peripheral tissue to insulin, reduction in number of insulin receptors cause increase in blood glucose level [1].

\section{Medicinal Plants to Treat Diabetes Mellitus:}

India has an officially recorded list of 45,000 plant species and a various estimation of 7500 species of medicinal importance [4]. India is rich source of various potent herbs and herbal components for treating diabetes. Many Indian plants have been examined for their beneficial use in different types of diabetes. In this review, there are 54 plants belonging to 36 families described about their uses in curing diabetes.

\begin{tabular}{|c|c|c|c|}
\hline S.no & $\begin{array}{c}\text { Common } \\
\text { name }\end{array}$ & $\begin{array}{c}\text { Botanical } \\
\text { name }\end{array}$ & Family \\
\hline 1. & Yam & $\begin{array}{l}\text { Dioscorea } \\
\text { opposite }\end{array}$ & Dioscoreaceae \\
\hline 2. & $\begin{array}{l}\text { Madhu } \\
\text { nashini }\end{array}$ & $\begin{array}{l}\text { Gymnema } \\
\text { sylvestre }\end{array}$ & Asclepidaceae \\
\hline 3. & $\begin{array}{l}\text { Karela, } \\
\text { bitter guard }\end{array}$ & $\begin{array}{l}\text { Momordica } \\
\text { charentia }\end{array}$ & Cucurbitaceae \\
\hline 4. & Neem & $\begin{array}{l}\text { Azadirachta } \\
\text { indica }\end{array}$ & Meliaceae \\
\hline 5. & Sweet flag & $\begin{array}{l}\text { Acorus } \\
\text { calamus }\end{array}$ & Acoraceae \\
\hline 6. & Jelly plum & $\begin{array}{l}\text { Sclerocarya } \\
\text { birrea }\end{array}$ & Anacardiaceae \\
\hline 7. & Sugar apple & $\begin{array}{l}\text { Annona } \\
\text { squamosal }\end{array}$ & Annonaceae \\
\hline 8. & Ashoka & $\begin{array}{l}\text { Polyalthia } \\
\text { longifolia }\end{array}$ & Annonaceae \\
\hline 9. & Hing 12 & $\begin{array}{l}\text { Ferula } \\
\text { asafetida }\end{array}$ & Apiaceae \\
\hline 10. & periwinkle & $\begin{array}{l}\text { Catharanthus } \\
\text { roseus }\end{array}$ & Apocynaceae \\
\hline 11. & $\begin{array}{l}\text { black } \\
\text { creeper }\end{array}$ & $\begin{array}{l}\text { Ichnocarpus } \\
\text { frutescens }\end{array}$ & Apocynaceae \\
\hline 12. & $\begin{array}{l}\text { Siberian } \\
\text { Ginseng }\end{array}$ & $\begin{array}{l}\text { Acanthopanax } \\
\text { senticosus }\end{array}$ & Araliaceae \\
\hline 13. & $\begin{array}{l}\text { Makad } \\
\text { Shing }\end{array}$ & $\begin{array}{l}\text { Caralluma } \\
\text { sinaica }\end{array}$ & Asclepidaceae \\
\hline 14. & Bahera & $\begin{array}{l}\text { Terminalia } \\
\text { bellerica }\end{array}$ & Combretaceae \\
\hline 15. & Keukand & $\begin{array}{l}\text { Costus } \\
\text { speciosus }\end{array}$ & Costaceae \\
\hline 16. & Sea bilberry & $\begin{array}{l}\text { Vaccinium } \\
\text { bracteatum }\end{array}$ & Ericaceae \\
\hline 17. & physic nut & $\begin{array}{l}\text { Jatropha } \\
\text { curcas }\end{array}$ & Euphorbiaceae \\
\hline 18. & Bushweed & $\begin{array}{l}\text { Securinega } \\
\text { virosa }\end{array}$ & Euphorbiaceae \\
\hline 19. & Amla & $\begin{array}{l}\text { Emblica } \\
\text { officinalis }\end{array}$ & Euphorbiaceae \\
\hline 20. & fenugreek & $\begin{array}{l}\text { Trigonella } \\
\text { foenum- } \\
\text { graecum }\end{array}$ & Fabaceae \\
\hline 21. & $\begin{array}{l}\text { matura tea } \\
\text { tree }\end{array}$ & $\begin{array}{l}\text { Senna } \\
\text { auriculata }\end{array}$ & Fabaceae \\
\hline 22. & Sandan & Ougeinia & Fabaceae \\
\hline
\end{tabular}


International Journal of Trend in Scientific Research and Development (IJTSRD) ISSN: 2456-6470

\begin{tabular}{|c|c|c|c|}
\hline & & oojeinensis & \\
\hline 23. & Dal chini & $\begin{array}{l}\text { Cinnamonum } \\
\text { zeylanicum }\end{array}$ & Lauraceae \\
\hline 24. & Onion & Allium cepa & Liliaceae \\
\hline 25. & $\begin{array}{l}\text { clearing-nut } \\
\text { tree }\end{array}$ & $\begin{array}{l}\text { Strychonous } \\
\text { potatorum }\end{array}$ & Loganiaceae \\
\hline 26. & Baobab & $\begin{array}{l}\text { Adansonnia } \\
\text { digitata }\end{array}$ & Malvaceae \\
\hline 27. & China rose & $\begin{array}{l}\text { Hibiscus rosa } \\
\text { sinensis }\end{array}$ & Malvaceae \\
\hline 28. & Banyan & $\begin{array}{l}\text { Ficus } \\
\text { benghalensis }\end{array}$ & Moraceae \\
\hline 29. & $\begin{array}{l}\text { cluster fig } \\
\text { tree }\end{array}$ & $\begin{array}{l}\text { Ficus } \\
\text { Glomerata }\end{array}$ & Moraceae \\
\hline 30. & peepul tree & $\begin{array}{l}\text { Ficus } \\
\text { religiosa }\end{array}$ & Moraceae \\
\hline 31. & Guava & $\begin{array}{l}\text { Psidium } \\
\text { guajava }\end{array}$ & Myrtaceae $5 \mathrm{C}$ \\
\hline 32. & Jamun & $\begin{array}{l}\text { Syzygium } \\
\text { cumini }\end{array}$ & Myrtaceae \\
\hline 33. & Lajalu & $\begin{array}{l}\text { Biophytum } \\
\text { sensitivum }\end{array}$ & Oxalidaceae \\
\hline 34. & $\begin{array}{l}\text { Black- } \\
\text { Honey } \\
\text { Shrub }\end{array}$ & $\begin{array}{l}\text { Phyllanthus } \\
\text { reticulatus }\end{array}$ & $\begin{array}{l}\text { Phyllanthaceae } \\
\text { Internatio }\end{array}$ \\
\hline 35. & $\begin{array}{l}\text { patience } \\
\text { dock }\end{array}$ & $\begin{array}{l}\text { Rumex } \\
\text { patientia }\end{array}$ & $\begin{array}{c}\text { Polygonaceae } \\
\text { Rese? }\end{array}$ \\
\hline 36. & $\begin{array}{l}\text { Neptune } \\
\text { grass }\end{array}$ & $\begin{array}{l}\text { Posidonia } \\
\text { oceanica }\end{array}$ & Posidoniaceae \\
\hline 37. & $\begin{array}{l}\text { black } \\
\text { mangrove }\end{array}$ & $\begin{array}{l}\text { Bruguiera } \\
\text { gymnorrhiza }\end{array}$ & $\begin{array}{c}\text { Rhizophoraceae } \\
\text { ISSN: }\end{array}$ \\
\hline 38. & Bael fruits & $\begin{array}{l}\text { Aegle } \\
\text { marmelos }\end{array}$ & Rutaceae \\
\hline 39. & $\begin{array}{l}\text { Mithijar, } \\
\text { Pilu }\end{array}$ & $\begin{array}{l}\text { Salvadora } \\
\text { oleoides }\end{array}$ & Salvadoraceae \\
\hline 40. & $\begin{array}{l}\text { Mithijar, } \\
\text { Pilu }\end{array}$ & $\begin{array}{l}\text { Salvadora } \\
\text { tamariscina }\end{array}$ & Selaginellaceae \\
\hline 41. & $\begin{array}{l}\text { Wild } \\
\text { eggplant }\end{array}$ & $\begin{array}{l}\text { Solanum } \\
\text { xanthocarpum }\end{array}$ & Solanaceae \\
\hline 42. & bay cedar & $\begin{array}{l}\text { Guazuma } \\
\text { ulmifolia }\end{array}$ & Sterculiaceae \\
\hline 43. & $\begin{array}{l}\text { Sambhalu, } \\
\text { mewri }\end{array}$ & $\begin{array}{l}\text { Vitex } \\
\text { negundo }\end{array}$ & Verbanaceae \\
\hline 44. & Babul & $\begin{array}{l}\text { Acacia } \\
\text { Arabica }\end{array}$ & Leguminoceae \\
\hline 45. & Aam & $\begin{array}{l}\text { Mangifera } \\
\text { indica }\end{array}$ & Anacardiaceae \\
\hline 46. & Garlic & $\begin{array}{l}\text { Allium } \\
\text { sativum }\end{array}$ & Liliaceae \\
\hline 47. & $\begin{array}{l}\text { Indian } \\
\text { black berry }\end{array}$ & $\begin{array}{l}\text { Eugenia } \\
\text { jambolana }\end{array}$ & Myrtaceae \\
\hline
\end{tabular}

\begin{tabular}{|c|c|c|c|}
\hline 48. & Sugarleaf & $\begin{array}{l}\text { Stevia } \\
\text { rebaudiana }\end{array}$ & Asteraceae \\
\hline 49. & Sandalwood & $\begin{array}{l}\text { Adenanthera } \\
\text { pavonina }\end{array}$ & Leguminosae \\
\hline 50. & $\begin{array}{l}\text { Asian } \\
\text { gingseng }\end{array}$ & Panax ginseng & Araliaceae \\
\hline 51. & $\begin{array}{l}\text { apple } \\
\text { blossom } \\
\text { tree }\end{array}$ & $\begin{array}{l}\text { Cassia } \\
\text { javanica }\end{array}$ & Fabaceae \\
\hline 52. & Tulsi & $\begin{array}{l}\text { Ocimum } \\
\text { sanctum }\end{array}$ & Lamiaceae \\
\hline 53. & clove basil & $\begin{array}{l}\text { Ocimum } \\
\text { Gratissimum }\end{array}$ & Lamiaceae \\
\hline 54. & waterleaf & $\begin{array}{l}\text { Talinum } \\
\text { Triangulare }\end{array}$ & Portulacaceae \\
\hline
\end{tabular}

Table no.1 Medicinal plants used to treat diabetes.

[1] Dioscorea opposite (DIOSCOREACEA):

Dioscorea opposite is commonly known as Yam belong to family dioscoreaceae. Constitute of yam have a lower glycemic index than costituents of potato, it means yam will provide a more sustained form of energy, and give better protection against obesity and diabetes [5].

\section{[2] Gymnema sylvestre (ASCLEPIDACEAE):}

The drugs consist of dried leaves of Gymnema sylvestre belonging to Family Asclepidaceae [6]. According to the horticultural department at Purdue University, it has been used in India for the treatment of diabetes for 2000 years. These drug constituents are useful for the control and treatment of diabetes mellitus.

\section{[3] Momordica charentia (CUCURBITACEAE):}

Extracts of fruit pulp, seed, leaves and whole plant was shown to have antidiabetic and antihyperglycemic activity in India as well as other Asian countries. Polypeptide $p$, isolated from fruit, seeds and tissues of $\mathrm{M}$. charantia showed significant hypoglycemic effect when administered subcutaneously to langurs and humans [7]. Alcoholic extracts of M. charantia (200 $\mathrm{mg} / \mathrm{kg})$ showed an antihyperglycemic and also hypoglycemic effect in normal and Straptozotocin induced diabetic rats. This may be because of inhibition of glucose-6phosphatase besides fructose-1, 6- biphosphatase in the liver and stimulation of hepatic glucose- 6phosphate dehydrogenase activities [8].

[4] Azadirachta indica (MELIACEAE):

Hydroalcoholic extract of neem shows antihyperglycemic activity in streptozocin induced 
diabetic rats and this effect is due to increase in glucose uptake and glycogen deposition in isolated rat hemidiaphragm [9]. Apart from having anti-diabetic activity, this plant also has anti-bacterial, antimalarial, antifertility, hepatoprotective and antioxidant effects.

[5] Acorus calamus (ACORACEAE):

Orally administered methanolic extract of A. calamus rhizome restored the levels of blood glucose in Streptozotocin induced diabetic rats after 21 days. Additional, lipid profile (total cholesterol, LDL and HDL-cholesterol), glucose 6-phosphatase, fructose 1,6 bis phosphatase levels and hepatic markers enzymes (aspartate aminotransferase, alanine aminotransferase, alkaline phosphatase) were decreased [10].

\section{[6] Sclerocarya birrea (ANACARDIACEAE):}

The methylene chloride/methanol extract (150 and $300 \mathrm{mg} / \mathrm{kg} \mathrm{bw}$ ) of Sclerocarya birrea stem bark significantly reduced the blood glucose level, plasma cholesterol, triglyceride and urea levels near the normal level and increased plasma insulin level in Straptozotocin induced diabetic rats [11].

\section{[7] Annona squamosa (ANNONACEAE):}

Aqueous extract of A. squamosa root (at a dose of 250 $\mathrm{mg} / \mathrm{kg}$ and $500 \mathrm{mg} / \mathrm{kg} \mathrm{bw}$ ) when administered to Straptozotocin- induced diabetic rats reduced the blood glucose level from 285.52 to $208.81 \mathrm{mg} / \mathrm{dl}$, after 6 hours of oral administration of extract [12].

\section{[8] Polyalthia longifolia (ANNONACEAE):}

Methanolic extract of p.longifolia bark when administered orally, reduced the fasting blood glucose. additionally the elevated levels of SGOT, SGPT, ALP, triglycerides and total cholesterol were restored to near normal level in Straptozotocin induced diabetic rats [13].

[9] Ferula asafoetida (APIACEAE):

In traditional medicine system, Oleo-gum-resin obtained from the roots of Ferula asafoetida, is used for the treatment of different diseases like gastrointestinal disorders, epilepsy, influenza and asthma. The hypoglycemic activity of Asafoetida was estimated in streptozotocin induced Male Wistar diabetic rats. The asafoetida extract showed significant hypoglycemic activity at dose of $50 \mathrm{mg} / \mathrm{kg}$ for 4 weeks, indicative of the presence of the tannins and phenolic acids (ferulic acid) in the extract [14].

[10] Catharanthus roseus (APOCYNACEAE):

Administration of leaf powder $(100 \mathrm{mg} / \mathrm{kg} \mathrm{bw})$ of C.roseus reduced the plasma glucose and increased the plasma insulin were obsereved after 15 days in straptozocin induced diabetic rats. The significant enhancement in plasma total cholesterol, triglycerides, LDL and VLDL cholesterol, and the atherogenic index of diabetic rats were normalized in extract treated diabetic rats [15].

\section{[11] Ichnocarpus frutescens (APOCYNACEAE):}

Orally administered polyphenolic extract of I. frutescens $(150$ and $300 \mathrm{mg} / \mathrm{kg} \quad$ bw $)$ leaves significantly reduced the fasting blood glucose levels, hepatic HMG-CoA reductase activity decreased the total cholesterol, triglyceride, VLDL, HDL and LDL level in alloxan induced diabetic Rats [16].

\section{[12] Acanthopanax senticosus (ARALIACEAE):}

A hot water extract at $85-95^{\circ} \mathrm{C}$ of A. senticosus stem bark significantly decreased the plasma glucose level without affecting plasma insulin levels and inhibited $\alpha$-glucosidase activity in diabetic mice. The addition of A. senticosus extract inhibited $\alpha$-glucosidase activity but not $\alpha$-amylase activity. Thus it would be useful as an component of functional foods to improve postprandial hyperglycemia and prevent type II diabetes mellitus [17].

\section{[13] Caralluma sinaica (ASCLEPIADACEAE):}

Acoholic extract of C. sinaica $(200 \mathrm{mg} / \mathrm{kg}$ bw) roots and aerial parts significantly reduced blood glucose level in Straptozotocin induced diabetic rat [18].

\section{[14] Terminalia bellerica (COMBRETACEAE):}

Crude extracts of $\mathrm{T}$. bellerica with hexane $(200 \mathrm{mg} / \mathrm{kg}$ bw), ethylacetate $(300 \mathrm{mg} / \mathrm{kg}$ bw) and methanol (300 $\mathrm{mg} / \mathrm{kg}$ bw) fruits significantly reduced the blood glucose level, total cholesterol, triglycerides, LDL cholesterol level, urea, uric acid, creatinine and serum total protein level while it increased the plasma insulin level of Straptozotocin induced diabetic rats [19].

\section{[15] Costus speciosus (COSTACEAE):}

Eremanthin is a compound isolated from the plant $\mathrm{C}$. speciosus rhizome. Orally administered Eremanthin decreased the HbAlc, serum total cholesterol, triglyceride, LDL-cholesterol level and at the same time markedly increased plasma insulin, tissue glycogen, HDL-cholesterol and serum protein of Straptozotocin induced diabetic rats. It also restored the plasma enzyme levels to near normal. Thus it possessed asignificant hypoglycemic and hypolipidemic activities and hence it could be used as a drug for treatment of diabetes [20].

\section{[16] Vaccinium bracteatum (ERICACEAE):}

Aqueous and ethanolic extract of V. bracteatum leaves significantly ameliorated the body weight, 
blood glucose, insulin and plasma lipid levels of Straptozotocin induced diabetic mice when administered intra-gastrically. The effect of $\mathrm{V}$. bracteatum aqueous extract on the diabetic mice was better effective than $\mathrm{V}$. bracteatum ethanolic extract [21].

\section{[17] Jatropha curcas (EUPHORBIACEAE):}

Oral administration of ethanolic extract of $\mathrm{J}$. curcas leaves $(250 \& 500 \mathrm{mg} / \mathrm{kg}$ bw) significantly reduced the blood glucose level and can therefore be used as an alternative remedy for the treatment of diabetes mellitus and its complications [22].

\section{[18] Securinega virosa (EUPHORBIACEAE):}

Intra-peritoneal administration of $(100,300$ and 600 $\mathrm{mg} / \mathrm{kg}$ bw) methanol extract from S. virosa leaves significantly reduced the blood glucose level of Straptozotocin induced diabetic rats [23].

[19] Emblica officinalis (EUPHORBIACEAE): Hydro-methanolic (20:80) extract of Emblica officinalis leaves was administered in diabetic rats at different doses to study the anti-diabetic effects using glibenclamid as standard. The extract showed improved blood glucose and serum insulin level at a noteworthy significance and showed significant decrease in biochemical parameters. The extract also improved the free radicals scavenging and antioxidant enzymes; superoxide dismutase, catalase, glutathione peroxidase and glutathione in dose dependent way [24].

[20] Trigonella foenum-graecum (FABACEAE):

Seeds and leaves of the Trigonella foenum-graecum are most frequently used parts of the plant. The antihyperglycemic effect of Trigonella foenumgraecum is due to decrease in somatostatin and high plasma glucagon levels [25] while the antihyperglycemic effect of fenugreek is due to the amino acid 4-hydroxyisoleucine which acts by the improvement of insulin sensitivity and glucose uptake in peripheral tissues [26].

\section{[21] Senna auriculata (FABACEAE):}

Ethanolic extract of S. auriculata (at a dose of 150 $\mathrm{mg} / \mathrm{kg}$ of bw) leaf significantly reduced the blood glucose level, SGOT, SGPT, ALP, total cholesterol, triglyceride and low density lipoprotein-cholesterol levels to the normal level and significantly increased HDL-C and phospholipid level in alloxan induced diabetic rats [27].

\section{[22] Ougeinia oojeinensis (FABACEAE):}

The ethanolic extract of O. oojeinensis $(200 \mathrm{mg} / \mathrm{kg})$ bark significantly decreased the blood glucose level, triglycerides, LDL, VLDL and total cholesterol and increased high density lipoprotein level in alloxan induced diabetic rats [28].

\section{[23] Cinnamonum zeylanicum (LAURACEAE):}

Aquous extract of cinnamonum zeylanicum significantly reduced total cholesterol, triglyceride, LDL-cholesterol and VLDL-cholesterol levels in streptozocin induced diabetic animal and elevated the tissue glycogen and HDL-cholesterol significantly [29]. Extract also showed improvement in glucose homeostatic enzymes indicating the antidiabetic activity of the extract.

\section{[24] Allium cepa (LILIACEAE):}

Various ether soluble fractions as well as insoluble fractions of dried onion powder show an hypoglycemic activity in diabetic rabbits. Administration of a sulfur containing amino acid from Allium cepa, S-methyl cysteine sulphoxide (200 $\mathrm{mg} / \mathrm{kg}$ for 45 days) to alloxan induced diabetic rats significantly controlled blood glucose as well as lipids in serum and tissues and normalized the activities of liver hexokinase, glucose 6-phosphatase and HMG Co A reductase [30]. When diabetic patients were given single oral dose of $50 \mathrm{~g}$ of onion juice, it significantly controlled post-prandial glucose levels [31].

\section{[25] Strychonous potatorum (LOGANIACEAE):}

Ethanolic extract of S. potatorum plant material significantly decreased the AST, ALT and ALP level along with reduction of blood glucose level in alloxan induced diabetic rats when

Administered Orally[32].

\section{[26] Adansonnia digitata (MALVACEAE):}

Methanolic extract of A. digitata stem bark (100 $\mathrm{mg} / \mathrm{kg}$ bw) significantly decreased the blood glucose level of Straptozotocin-induced diabetic Wistar rats when administered intra-peritoneally [33].

\section{[27] Hibiscus rosa sinensis (MALVACEAE):}

Aqueous extract of aerial part of $\mathrm{H}$. rosa sinensis (500 mg kg-1) reduced the blood glucose level, urea, uric acid and creatinine While increased the activities of insulin, C-peptide, albumin, albumin/globulin ratio and restored all marker enzymes to near control levels of Straptozotocin-induced diabetic rats. Thus, it exhibited a hypoglycemic effect and consequently may alleviate liver and renal damage associated with Straptozotocin-induced diabetes mellitus in rats [34].

[28] Ficus benghalensis (MORACEAE): 
The aqueous extract of stem bark of $\mathrm{F}$. bengalensis significantly reduced the blood glucose level in Straptozotocin induced diabetic rats [35].

\section{[29] Ficus Glomerata (MORACEAE):}

The ethanolic extract of F. Glomerata leaves reduced the blood glucose, serum urea, creatinine and cholesterol level in alloxan induced diabetic rats [36].

\section{[30] Ficus religiosa (MORACEAE):}

Aqueous extract of $\mathrm{F}$. religiosa bark significantly reduced the blood glucose level and increased the serum insulin level, glycogen content in liver and skeletal muscle in Straptozotocin-induced diabetic rats when administered orally [37].

[31] Psidium guajava (MYRTACEAE):

A hot aquous extract of $P$. guajava unripe fruit peel $(400 \mathrm{mg} / \mathrm{kg}$ ) significantly decreased the triglyceride, total cholesterol, alkaline phosphatase, asperate amino transferase, alanine amino transferase and creatinine levels in Straptozotocin induced diabetic rats [38].

\section{[32] Syzygium cumini (MYRTACEAE):}

Mycaminose is a compound isolated from the plant $\mathrm{S}$. cumini seed extract. Oral administration of a Mycaminose $(50 \mathrm{mg} / \mathrm{kg})$, ethyl acetate $(200 \mathrm{mg} / \mathrm{kg})$ and methanol extracts $(400 \mathrm{mg} / \mathrm{kg})$ of fruits and leaves of S. cumini reduced the blood glucose level in Straptozotocin-induced diabetic rats [39].

\section{[33] Biophytum sensitivum (OXALIDACEAE):}

Ethanolic extract of $B$. sensitivum whole plant significantly decreased the blood glucose level, serum cholesterol level and increased the total protein level in alloxan induced diabetic rats when administered orally [40].

\section{[34] Phyllanthus}

(PHYLLANTHACEAE):

reticulatus

Ethanolic and petroleum ether extracts of $P$. reticulatus $(1000 \mathrm{mg} / \mathrm{kg})$ leaves significantly reduced the blood glucose level in alloxan induced diabetic rats [41].

\section{[35] Rumex patientia (POL YGONACEAE):}

R. patientia showed reduction in serum glucose level, LDL cholesterol level and increased the HDL cholesterol level in Straptozotocin induced diabetic rats when it supplemented with seed powder [42].

[36] Posidonia oceanica (POSIDONIACEAE):

The hydroalcoholic extract of P. oceanica leaves (150 and $250 \mathrm{mg} / \mathrm{kg} \mathrm{bw}$ ) significantly reduced the blood glucose level, ALP, GSH, SOD, GPx, CAT, GPT and nitric oxide level to the normal level in alloxan induced diabetic rats [43].
[37] Bruguiera

gymnorrhiza

(RHIZOPHORACEAE):

Ethanolic extract of B. gymnorrhiza root $(400 \mathrm{mg} / \mathrm{kg}$ b.wt) significantly decreased the blood sugar level, total cholesterol, triglycerides, VLDL and LDL and significantly increased the HDL level in Straptozotocin induced diabetic rats when administered orally [44].

\section{[38] Aegle marmelos (RUTACEAE):}

Aqueous extract of leaves of aegle marmelos improves digestion and reduces blood sugar and urea, serum cholesterol in alloxan induced diabetic rats as compared to control. Along with exhibiting hypoglycemic activity, this extract also prevented peak rise in blood sugar at $1 \mathrm{~h}$ in oral glucose tolerance test [45].

\section{[39] Salvadora oleoides (SALVADORACEAE):}

Oral administration of ethanolic extract of S. oleoides ( 1 and $2 \mathrm{~g} / \mathrm{kg} \mathrm{bw}$ ) aerial parts significantly reduced the blood glucose level and improves lipid profile in euglycemic as well as alloxan induced diabetic rats [46].

[40] Ournal Salvadora

tamariscina

(SELAGINELLACEAE):

The ethanolic extracts of S. tamariscina whole plant ameliorated the fasting blood glucose level and improved oral glucose tolerance in STRAPTOZOCIN induced diabetic rats [47]. It also significantly down the total cholesterol (TC), triglyceride (TG), LDL-c, free fatty acids (FFA) tumor necrosis factor (TNF), ALT, AST, blood urea nitrogen (BUN) and malondialdehyde (MDA) levels in diabetic rats [47].

\section{[41] Solanum xanthocarpum (SOLANACEAE):}

The methanolic extract of the leaves of $S$. xanthocarpum significantly reduced the blood glucose level, urea, uric acid and creatinine level and increased the serum insulin level in alloxan induced diabetic rats when administered orally [48].

[42] Guazuma ulmifolia (STERCULIACEAE):

Extract of G. ulmifolia bark induced the glucose uptake in insulin-resistant adipocytes. It exerted its anti-diabetic effects by stimulating glucose uptake in both insulin sensitive and insulin resistant adipocytes without inducing adipogenesis [49].

\section{[43] Vitex negundo (VERBANACEAE):}

$\mathrm{V}$. negundo contain active component called as Idopyranose. It reduced the blood glucose level, serum urea, and cholesterol level in STRAPTOZOCIN-induced diabetic rats. It helped to regenerate the damaged pancreas and protected the 
pancreatic $\beta$ cells and hyperglycemic in nature against Straptozotocin-induced diabetic rats [50].

\section{[44] Acacia Arabica (LEGUMINOCEAE):}

Plant extract shows an antidiabetic activity by acting as secretagouge to release insulin from pancrease. It induces hypoglycemia in control rats but not in alloxan induced animals. Powdered seeds of Acacia arabica when administered to normal rabbits induced hypoglycemic effect by initiating release of insulin from pancreatic beta cells [51].

\section{[45] Mangifera indica (ANACARDIACEAE):}

Aqueous extract given orally did not alter blood glucose level in either normoglycemic or streptozotocin induced diabetic rats. Its antidiabetic activity was seen when the extract and glucose were administered simultaneously and also when the extract was given to the rats one hour before the intake of glucose. The results point out that aqueous extract of Mangifera indica possess hypoglycemic activity. This occur due to reduction in absorption of glucose from intestinal wall [52].

\section{[46] Allium sativum (LILIACEAE):}

Allium sativum act as an antidiabetic agent by increasing either the pancreatic secretion of insulin from the $\beta$ cells or the release of bound insulin [53]. Allicin is a sulfur-containing compound which is responsible for its pungent flavour and significant hypoglycemic activity. Garlic alone and with ginger and turmeric when tested against oxidative stress in streptozotocin-nicotinamide induced diabetic rats showed increment in the signs of hyperglycaemia and dyslipidaemia [54].

\section{[47] Eugenia jambolana (MYRTACEAE):}

The hypoglycemic activity of Eugenia jambolana is due to increased secretion of insulin from the pancreas or by inhibition of insulin degradation [55]. In India decoction of kernels of Eugenia jambolana is used as household remedy for diabetes. This also forms a major constituent of many herbal formulations for diabetes. Its aquous and alcoholic extract shows significant hypoglycemic effect. This varies with different level of diabetes. In mild diabetes (plasma sugar $>180 \mathrm{mg} / \mathrm{dl}$ ) it shows $73.51 \%$ reduction, whereas in moderate (plasma sugar $>280 \mathrm{mg} / \mathrm{dl}$ ) and severe diabetes (plasma sugar $>400 \mathrm{mg} / \mathrm{dl}$ ) it is reduced to $55.62 \%$ and $17.72 \%$ respectively. The extract of pulp showed the hypoglycemic activity in streptozotocin induced diabetic mice within $30 \mathrm{~min}$ of administration while the seed of the same fruit required $24 \mathrm{~h}$. Extracts also inhibited insulinase activity from liver and kidney [56].

\section{[48] Stevia rebaudiana (ASTERACEAE):}

Aqueous extract of Stevia rebaudiana in combination with Momordicha charantia, Tamarindus indica, Gymnema sylvestre, Allium sativum and Murraya koenigii were evaluated for antidiabetic activity in the form of different polyherbal combinations. All combinations were safe and dose of $250 \mathrm{mg} / \mathrm{kg}$ was selected as antidiabetics [57].

\section{[49] Adenanthera pavonina (LEGUMINOCEAE):}

Antihyperglycaemic and lipid lowering effects of A. pavonina seed aqueous extract was evaluated in the streptozotocin induced diabetic rats. Treatment with Adenanthera pavonina extract showed considerable decrease in plasma glucose, elevated levels of serum triglyceride and cholesterol levels were significantly decreased. Treatment for 30 days showed significant decrease in serum LDL-cholesterol and significant increase in serum HDL cholesterol level and elevated the levels of $\mathrm{HbAlc}$ which was significantly increased indicating that extract has the potential to treat diabetes condition and associated lipid disorders [58].

\section{[50] Panax ginseng (ARALIACEAE):}

Antidiabetic efficiency of $P$. ginseng berry extract was evaluated in streptozotocin induced diabetic mice. Hypoglycemic potential of extract in beta-cell deficient mice was evaluated and mechanisms involved were evaluated. Extract showed promising results stimulating increased insulin secretion indicating beta-cell regeneration and improved glycemic control [59].

\section{[51] Cassia javanica (FABACEAE):}

Hypoglycemic ability of Cassia javanica wasevaluated in streptozotocin induced diabetic rats. First of all, drug was used to test acute oral toxicity. Formerly, phytochemistry of drug was checked by standard qualitative tests thus detecting antidiabetic compounds. The test drug and standard drug demonstrated considerable fluctuations in the abnormal levels of serum metabolites of diabetic rats [60].

\section{[52] Ocimum sanctum (LAMIACEAE):}

Aqueous extract of Ocimum sanctum was evaluated for the antioxidant potential in streptozotocin-induced diabetic rats. Extract decreased the levels of thiobarbituric acid reacting substances in plasma and improved conditions of the antioxidant enzymes; glutathione peroxidase, superoxide dismutase and catalase in essential organs like kidney and liver when administered orally. Results indicated that Ocimum 
sanctum might be an important herbal medicine for curing diabetic complications [61].

[53] Ocimum Gratissimum (LAMIACEAE):

O. gratissimum reduces blood sugar level in diabetic rats and improve the cardinal symptoms of diabetes mellitus namely; polyphagia, polydypsia and weight loss when its aquous leaf extract was administered orally in streptozotocin induced diabetic rats [62].

[54] Talinum Triangulare (PORTULACACEAE): Antihyperglcemic effects of Talinum Triangulare were evaluated in streptozotocin induced diabetic animals. Extract of T. Triangulare significantly reduced the blood glucose levels in diabetic and normal glucose loaded rats. Oral glucose tolerance test showed significant hypoglycemia in rats. The use of glipizide with extract shows significant synergistic effect [63].

\begin{tabular}{|c|c|c|c|}
\hline $\begin{array}{l}\text { S. } \\
\text { no }\end{array}$ & $\begin{array}{l}\text { Market } \\
\text { ed } \\
\text { formula } \\
\text { tion }\end{array}$ & Ingredients & $\begin{array}{l}\text { Manufact } \\
\text { urer }\end{array}$ \\
\hline 1. & Asanand & $\begin{array}{l}\text { Ganasar,Arjuna,Lodhra, } \\
\text { Karanja,Kanth, Shirish, } \\
\text { Palash }\end{array}$ & $\begin{array}{l}\text { Ayurveda } \\
\text { Rasashala } \\
\text { Pune. }\end{array}$ \\
\hline 2. & $\begin{array}{l}\text { Alangiu } \\
\text { m } \\
\text { salvifoli } \\
\text { um } \\
\text { Tablet } \\
\end{array}$ & $\begin{array}{l}\text { Alangium salvifolium, } \\
\text { Gycin max }\end{array}$ & $\begin{array}{l}\text { PSK } \\
\text { Herbal S } \\
\text { Technolog } \\
\text { y }\end{array}$ \\
\hline 3. & $\begin{array}{l}\text { Ipomea } \\
\text { digitata } \\
\text { tablet }\end{array}$ & Ipomea digitata & $\begin{array}{l}\text { The } 1 N: 24 \\
\text { Himalaya } \\
\text { Drug } \\
\text { Company }\end{array}$ \\
\hline 4. & $\begin{array}{l}\text { Bitter } \\
\text { gourd } \\
\text { tablets }\end{array}$ & Momordica charantia & $\begin{array}{l}\text { Garry and } \\
\text { Sun } \\
\text { natural } \\
\text { Remedies }\end{array}$ \\
\hline 5. & $\begin{array}{l}\text { Diabet } \\
\text { capsule }\end{array}$ & $\begin{array}{l}\text { Curcuma longa, } \\
\text { Coscinium fenestratum, } \\
\text { Strychnos } \\
\text { potatorum, Tamarindus } \\
\text { indica, Tribulus } \\
\text { terrestris, } \\
\text { Phyllanthus reticulates } \\
\end{array}$ & $\begin{array}{l}\text { La- } \\
\text { medicca } \\
\text { private } \\
\text { limited }\end{array}$ \\
\hline 6. & $\begin{array}{l}\text { Dihar } \\
\text { powder }\end{array}$ & $\begin{array}{l}\text { Syzygium cumini, } \\
\text { Momordica charantia, } \\
\text { Emblica } \\
\text { officinalis, Gymnema } \\
\text { sylvestre, Enicostemma } \\
\text { littorale, }\end{array}$ & $\begin{array}{l}\text { Rajsha } \\
\text { pharmaceu } \\
\text { ticals }\end{array}$ \\
\hline
\end{tabular}

\begin{tabular}{|c|c|c|c|}
\hline & & $\begin{array}{l}\text { Azadirachta indica, } \\
\text { Tinospora cordifolia, } \\
\text { Curcuma longa }\end{array}$ & \\
\hline 7. & Shilajeet & Shudha shilajeet & $\begin{array}{l}\text { Ayurveda } \\
\text { Rasashala } \\
\text { Pune }\end{array}$ \\
\hline 8. & $\begin{array}{l}\text { Triphala } \\
\text { Guggul }\end{array}$ & Triphala guggul & $\begin{array}{l}\text { Ayurveda } \\
\text { Rasashala } \\
\text { Pune }\end{array}$ \\
\hline 9. & $\begin{array}{l}\text { Gokshur } \\
\text { adi } \\
\text { Guggul }\end{array}$ & Gokshuradi guggul & $\begin{array}{l}\text { Ayurveda } \\
\text { Rasashala } \\
\text { Pune }\end{array}$ \\
\hline 10. & $\begin{array}{l}\text { Trivang } \\
\text { Bhasma }\end{array}$ & Trivang bhasma & $\begin{array}{l}\text { Ayurveda } \\
\text { Rasashala } \\
\text { Pune. }\end{array}$ \\
\hline 11. & $\begin{array}{l}\text { Lohasav } \\
\text { a }\end{array}$ & Lohabasma & $\begin{array}{l}\text { Ayurveda } \\
\text { Rasashala } \\
\text { Pune }\end{array}$ \\
\hline 12. & $\begin{array}{l}\text { Giloysa } \\
\text { va }\end{array}$ & Giloysatva & $\begin{array}{l}\text { Ayurveda } \\
\text { Rasashala } \\
\text { Pune }\end{array}$ \\
\hline 13. & $\begin{array}{l}\text { Mamajo } \\
\mathrm{v} \\
\text { ouring }\end{array}$ & Mamajov powder & $\begin{array}{l}\text { Ambadas } \\
\text { vanaushad } \\
\text { halaya }\end{array}$ \\
\hline 14. & $\begin{array}{l}\text { Diabetic } \\
\text { Powder }\end{array}$ & $\begin{array}{l}\text { Proprietary anti diabetic } \\
\text { herbs }\end{array}$ & $\begin{array}{l}\text { Rahul } \\
\text { Pharmacy } \\
\text { Gujarat }\end{array}$ \\
\hline 15. & $\begin{array}{l}\text { Indrajav } \\
\text { Churana }\end{array}$ & Indrajav churana & $\begin{array}{l}\text { Universal } \\
\text { Pharmacy } \\
\text { Pune }\end{array}$ \\
\hline 16. & Panvli & $\begin{array}{l}\text { Karvas,Yashti,Panvelle } \\
\text { y,Gudmar,Gul } \\
\text { vel,Kanth,Haldi,Amla }\end{array}$ & $\begin{array}{l}\text { Panvelly } \\
\text { Herbal } \\
\text { Product,R } \\
\text { ajkot }\end{array}$ \\
\hline 17. & $\begin{array}{l}\text { Madhum } \\
\text { ehari }\end{array}$ & $\begin{array}{l}\text { Vijaysar,Kutaj,Kulki,M } \\
\text { ethi,Shilajeet, } \\
\text { Trivang-Nag- } \\
\text { Suvarnamakshik bhasm }\end{array}$ & $\begin{array}{l}\text { Shrivaidya } \\
\text { nah, } \\
\text { Jhansi }\end{array}$ \\
\hline 18. & $\begin{array}{l}\text { Karnee } \\
\mathrm{m}\end{array}$ & $\begin{array}{l}\text { Karela,NeemTulsi,Kulk } \\
\text { i,Sounth,Sh } \\
\text { Udhaguggul }\end{array}$ & $\begin{array}{l}\text { Universal } \\
\text { Medicame } \\
\text { nt } \\
\text { Pvt.Ltd, } \\
\text { Nagpur }\end{array}$ \\
\hline 19. & $\begin{array}{l}\text { Hyponid } \\
\text { d }\end{array}$ & $\begin{array}{l}\text { Haldi,Jambuphal, } \\
\text { Trivangbhasm,Chirait, } \\
\text { Shilajeet, } \\
\text { Senna,Amla,Gudmar, } \\
\text { Kuaj,Gulvel }\end{array}$ & $\begin{array}{l}\text { Charak } \\
\text { Pharma } \\
\text { Pvt.Ltd.M } \\
\text { umbai }\end{array}$ \\
\hline 20. & Adcaps & $\begin{array}{l}\text { Haldi,Jambuphal,Amla, } \\
\text { Mamajov,N } \\
\text { eem,Karela,Vijaysar,Tej } \\
\text { bal,Gulvel }\end{array}$ & $\begin{array}{l}\text { Doctors } \\
\text { Pharmace } \\
\text { uticals }\end{array}$ \\
\hline
\end{tabular}


International Journal of Trend in Scientific Research and Development (IJTSRD) ISSN: 2456-6470

\begin{tabular}{|c|c|c|c|}
\hline & & $\begin{array}{l}\text { Sudha,Guggl, Trivang- } \\
\text { Nag- } \\
\text { Suvarnamakshik } \\
\text { bhasm,Shilajeet,Ashok, } \\
\text { Madhunasni }\end{array}$ & \\
\hline 21. & $\begin{array}{l}\text { Diabeco } \\
n\end{array}$ & $\begin{array}{l}\text { Gymnema sylvestre, } \\
\text { Pterocarpus marsupium, } \\
\text { Glycyrrhiza glabra, } \\
\text { Casearia } \\
\text { esculenta, Syzygium } \\
\text { cumini, Asparagus } \\
\text { racemosus, Boerhavia } \\
\text { diffusa, } \\
\text { Sphaeranthus indicus, } \\
\text { Tinospora cordifolia, } \\
\text { Swertia chirata, } \\
\text { Tribulus } \\
\text { terrestris, Phyllanthus } \\
\text { amarus, Gmelina } \\
\text { arborea, Gossypium } \\
\text { herbaceum, } \\
\text { Berberis aristata, Aloe } \\
\text { vera, Triphala, } \\
\text { Commiphora wightii, In } \\
\text { shilajeet, } \\
\text { Momordica charantia, } \\
\text { Piper nigrum, Ocimum } \\
\text { sanctum, Abutilon } \\
\text { indicum, } \\
\text { Curcuma longa, Rumex } \\
\text { maritimus }\end{array}$ & Himalaya \\
\hline 22. & $\begin{array}{l}\text { Pancreat } \\
\text { ic tonic } \\
180 \mathrm{cp}\end{array}$ & $\begin{array}{l}\text { Pterocarpus marsupium, } \\
\text { Gymnema sylvestre, } \\
\text { Momordica charantia, } \\
\text { Syzygium } \\
\text { cumini, Trigonella } \\
\text { foenum graceum, } \\
\text { Azadirachta indica, } \\
\text { Ficus racemosa, Aegle } \\
\text { marmelos, } \\
\text { Cinnamomum tamala }\end{array}$ & $\begin{array}{l}\text { ayu } \\
\text { herk } \\
\text { sup! }\end{array}$ \\
\hline 23. & Dia-care & $\begin{array}{l}\text { Sanjeevan Mool; Himej, } \\
\text { Jambu beej, Kadu, } \\
\text { Namejav, Neem chal. }\end{array}$ & $\begin{array}{l}\text { Admark } \\
\text { Herbals } \\
\text { Limited }\end{array}$ \\
\hline 24. & $\begin{array}{l}\text { Diabetes } \\
\text {-Daily } \\
\text { Care }\end{array}$ & $\begin{array}{l}\text { Alpha Lipoic Acid, } \\
\text { Cinnamon } 4 \% \text { Extract, } \\
\text { Chromax, Vanadium, } \\
\text { Fenugreek } \\
50 \% \text { extract, Gymnema } \\
\text { sylvestre } 25 \% \text { extract } \\
\text { Momordica } 7 \% \text { extract, } \\
\text { Licorice }\end{array}$ & $\begin{array}{l}\text { Nature's } \\
\text { Health } \\
\text { Supply }\end{array}$ \\
\hline
\end{tabular}

\begin{tabular}{|c|c|c|c|}
\hline & & Root $20 \%$ extract & \\
\hline 25. & $\begin{array}{l}\text { Gurmar } \\
\text { powder }\end{array}$ & $\begin{array}{l}\text { Gurmar (Gymnema } \\
\text { sylvestre) }\end{array}$ & $\begin{array}{l}\text { Garry and } \\
\text { Sun } \\
\text { natural } \\
\text { Remedies }\end{array}$ \\
\hline 26. & $\begin{array}{l}\text { Epinsuli } \\
\mathrm{n}\end{array}$ & $\begin{array}{l}\text { vijaysar (Pterocarpus } \\
\text { marsupium) }\end{array}$ & $\begin{array}{l}\text { Swastik } \\
\text { Formulati } \\
\text { ons }\end{array}$ \\
\hline 27. & $\begin{array}{l}\text { Diabecu } \\
\text { re }\end{array}$ & $\begin{array}{l}\text { Juglans regia, Berberis } \\
\text { vulgaris, Erytherea } \\
\text { centaurium, } \\
\text { Millefolium, Taraxacum }\end{array}$ & $\begin{array}{l}\text { Nature } \\
\text { beaute } \\
\text { santé }\end{array}$ \\
\hline 28. & Diabeta & $\begin{array}{l}\text { Gymnema sylvestre, } \\
\text { Vinca rosea } \\
\text { (Periwinkle), Curcuma } \\
\text { longa (Turmeric), } \\
\text { Azadirachta indica } \\
\text { (Neem), Pterocarpus } \\
\text { marsupium (Kino Tree), } \\
\text { Momordica } \\
\text { charantia (Bitter } \\
\text { Gourd), Syzygium } \\
\text { cumini (Black Plum), } \\
\text { Acacia arabica } \\
\text { (Black Babhul), } \\
\text { Tinospora cordifolia, } \\
\text { Zingiber officinale } \\
\text { (Ginger) }\end{array}$ & $\begin{array}{l}\text { Ayurvedic } \\
\text { cure } \\
\text { Ayurvedic } \\
\text { Herbal } \\
\text { Health } \\
\text { Products }\end{array}$ \\
\hline 29. & Syndrex & $\begin{array}{l}\text { Germinated Fenugreek } \\
\text { seed extract }\end{array}$ & $\begin{array}{l}\text { Plethico } \\
\text { Laboretari } \\
\text { es }\end{array}$ \\
\hline 30. & $\begin{array}{l}\text { Epinsuli } \\
\mathrm{n}\end{array}$ & Pterocarpus marsupium & $\begin{array}{l}\text { Swastik } \\
\text { Formulati } \\
\text { ons }\end{array}$ \\
\hline
\end{tabular}

\section{Table no.2 Marketed formulations and their ingredients used for Diabetes.}

\section{REFERENCES:}

1) KD Tripathy, Essentials of medical pharmacology, Seventh edition, 2013,Jaypee brothers medical publishers (P) ltd ,New Delhi, page no. 258

2) Seth, S.D. and Sharma, B.: Medicinal plants of India. Indian J. Med. Res., 120, 9-11, 2004.

3) Peter N Bennett, Morris J brown, Pankaj Sharma, Clinical Pharmacology, eleventh edition, 2012, Churchill Livingstone Elsevier international publication, page no. 572

4) Mishra RK, Jena BB, Mishra BK, Misra KC, Sarangi B.- Mortality events amongst non-insulin dependent diabetes mellitus patients in Odisha -.J 
Assoc Physicians India. 1991 Jul; 39 (7):519-20. Department of Medicine, SCB Medical College, Cuttack.

5) Ansari SH. Essentials of Pharmacognosy. First edition. Birla Prakashan, Delhi - 32 (2005-2006) 588-590.

6) Kokate CK. Purohit AP. and Gokhale SB. Pharmacognosy, $11^{\text {th }}$ edition, Nirali Prakashan (1999) 78-83.

7) Khanna, P., Jain, S.C., Panagariya, A., and Dixit, V.P.: Hypoglycemic activity of polypeptide- $\mathrm{p}$ from a plant source. J. Nat. Prod., 44, 648-655, 1981.

8) Shibib, B.A., Khan, L.A., and Rahman, R.: Hypoglycemic activity of Coccinia indica and Momordica charantia in diabetic rats: depression of the hepatic gluconeogenic enzymes glucose-6phosphatase and fructose-1, 6-biphosphatase and elevation of liver and red-cell shunt enzyme glucose-6-phosphate dehydrogenase. Biochem. J., 292, 267-270, 1993.

9) Chattopadhyay, R.R., Chattopadhyay, R.N., Nandy, A.K., Poddar, G., and Maitra, S.K.: The effect of fresh leaves of Azadiracta indica on glucose uptake and glycogen content in the isolated rat hemidiaphragm. Bull. Calcutta. Sch. Trop. Med., 35, 8-12, 1987.

10) Prisilla $D H$, Balamurugan $R$, Shah $H$, Antidiabetic activity of methanol extract of Acorus calamus in STRAPTOZOCIN induced diabetic rats, Asian Pac. J. Trop. Med, 2 (2012) S941.

11) Dimo T, Rakotonirina $S$ V, Tan $P$ V, Azay J, Dongo E, Kamtchouing P \& Cros G, Effect of Sclerocarya birrea stem bark methylene chloride/methanol extract of streptozotocininduced diabetic rats, J. Ethnopharmocol, 110 (2007) 434.

12) Mohd M, Alam K S, Mohd A, Abhishek M, \& Aftab A, Antidiabetic activity of the aqueous extract of Annona squamosa in Streptozotocin inducedhyperglycemic rats, T. Pharm. Res, 2 (2009) 59.

13) Ghosh G, Kar D M, Subudhi B B \& Mishra S K, Anti-hyperglycemic and antioxidant activity of stem bark of Polyalthia longifolia var. angustifolia, Der Pharmacia Lettre, 2 (2010) 206.

14) Kumavat, U.C., S.N. Shimpi, and S.P. Jagdale. (2012). Hypoglycemic activity of Cassia javanica Linn. in normal and streptozotocin-induced diabetic rats. Journal of advanced pharmaceutical technology \& research, 3(1), 47.
15) Rasineni K, Bellamkonda R, Singareddy S R, Desireddy S, Antihyperglycemic activity of Catharanthus roseus leaf powder in streptozotocin-induced diabetic rats, Phcog. Res, 2 (2010) 195.

16) Kumarappan $C \mathrm{~T}$, Rao $\mathrm{T} N$ \& Mandal $\mathrm{S} C$, Polyphenolic extract of Ichnocarpus frutescens modifies hyperlipidemia status in diabetic rats, J. Cell Mol. Biol, 6 (2007) 175.

17) Watanabe K, Kamata K \& Sato J, Fundamental studies on the inhibitory action of Acanthopanax senticosus Harms on glucose absorption. J Ethnopharmacol, 28 (2010) 193.

18) Habibuddin M, Daghriri H A, Al Qahtani M S \& Hefzi A A H, Antidiabetic effect of alcoholic extract of Caralluma sinaica L. on streptozotocininduced diabetic rabbits, J. Ethnopharmacol, 117 (2008) 215.

19) Latha R C R \& Daisy P, Influence of Terminalia bellerica Roxb. fruit extracts on Biochemical parameters in STRAPTOZOCIN Diabetic rats, Int. J. Pharmacol, 6 (2010) 89.

20) Eliza J, Daisy P, Ignacimuthu S \& Duraipandiyan $\mathrm{V}$, Antidiabetic and anti-lipidemic effect of eremanthin from Costus speciosus (Koen.)Sm., in STRAPTOZOCIN induced diabetic rats, Chem. Biol. Interact, 182 (2009) 67.

21) Li Wang, Zhang $X \mathrm{~T}$, Zhang $\mathrm{H} \mathrm{Y}$, Yao $\mathrm{H} \mathrm{Y \text {, }}$ Zhang H, Effect of Vaccinium bracteatum Thunb. leaves extract on blood glucose and plasma lipid levels in streptozotocin-induced diabetic mice, J Ethnopharmacol, 130 (2010) 465.

22) Mishra S B, Vijayakumjar M, Ojha S K \& Verma A, Antidiabetic effect of Jatropha

a. curcas L. leaves extract in normal and alloxan-induced diabetic rats, Int. J. Ph. Sci, 2 (2010) 482.

23) Tanko $Y$, Okasha M A, Magaji G M, Yerima M, Yaro A H, Saleh M I A \& Mohamme A, Anti diabetic properties of Securinega virosa (Euphorbiaceae) leaf extract, Afr. J. Biotechnol, 7 (2008) 022.

24) Nain, P., et al., (2012). Antidiabetic and antioxidant potential of Emblica officinalis Gaertn. leaves extract in streptozotocin-induced type-2 diabetes mellitus (T2DM) rats. Journal of Ethnopharmacology, 142(1), 65-71.

25) G. Ribes, Y. Sauvaire, C. Da Costa, and M. M. Loubatieres-Mariani, "Antidiabetic effects of subfractions from fenugreek seeds in diabetic dogs," Proceedings of the Society for 
Experimental Biology and Medicine, vol. 182, no.2, pp. 159-166, 1986.

26) A. B. Singh, A. K. Tamarkar, S. Shweta, T. Narender, and A.K. Srivastava, "Antihyperglycaemic effect of an unusual amino acid (4-hydroxyisoleucine) in C57BL/KsJ-db/db mice," Natural Product Research, vol. 24, no. 3, pp. 258-265, 2010.

27) Shanmugasundaram R, Devi $K K$, Soris $T P$, Maruthupandian A \& Mohan V R, Antidiabetic, antihyperlipidemic and antioxidant activity of Senna auriculata (L) Roxb. Leaves in alloxan induced diabetic rats, Int. J. Pharm Tech Res, 3 (2011) 747.

28) Velmurugan C, Sundaram T, Sampath Kumar R, Vivek B, Sheshadri Sekar D \& Ashok kumar B S, Anti Diabetic and Hypolipidemic Activity of Bark of Ethanolic Extract of Ougeinia Oojeinensis (ROXB.), Med J Malaysia, 66 (2011) 22.

29) Hassan, S.A., et al., (2012). Aqueous bark extract of Cinnamomum Zeylanicum: a potential therapeutic agent for streptozotocin-induced type 1 diabetes mellitus (T1DM) rats. Tropical Journal of Pharmaceutical Research, 11(3), 429-435.

30) Kumari, K., Mathew, B.C., and Augusti, K.T.: Antidiabetic and hypolipidaemic effects of CSmethyl cysteine sulfoxide, isolated from Allium cepa Linn. Ind. J. Biochem. Biophys., 32, 49-54, 1995.

31) Mathew, P.T. and Augusti, K.T.: Hypoglycemic effects of onion, Allium cepa Linn. on diabetes mellitus- a preliminary report. Ind. J. Physiol. Pharmacol., 19, 213-217, 1975.

32) Dhasarathan $P$ \& Theriappan $P$, Evaluation of antidiabetic activity of Strychonous potatorum in alloxan induced diabetic rats, J. Med. Med. Sci, 2 (2011) 670 .

33) Tanko K Y \& Mohammed A, Hypoglycemic activity of methanolic stem bark extract of Adansonnia digitata extract on blood glucose levels of streptozotocin-induced diabetic wistar rats, Int. J. Appl. Res. Nat. Prod, 1 (2008) 32.

34) Mandade R, \& Sreenivas S A, Antidiabetic effect of aqueous ethanolic extract of Hibiscus Rosa sinensis L .on Streptozotocin-induced Diabetic rats and the possible Morphologic changes in the Liver and Kidney, Int. J. pharmacol, 7 (2011) 363.

35) Gayathri M \& Kannabiran K, The effects of oral administration of an aqueous of Ficus benghalensis stem bark on some hematological and biochemical parameters in rats with streptozotocininduced diabetes, Turk. J. Biol, 33 (2009) 9.

36) Sharma V K, Kumar S, Patel H J \& Hugar S, Hypoglycaemic activity of Ficus glomerata in Alloxan induced diabetic rats, Int. J.Pharm. Sci. Res, 1(2010) 18.

37) Pandit R, Phadke A \& Aarti J, Antidiabtic effect of Ficus religiosa extract in streptozotocin induced diabetic rats, J Ethnopharmacol, 128 (2010) 462.

38) Rai P K, Mehta S \& Watal G, Hypolipidaemic \& hepatoprotective effects of Psidium guajava raw fruit peel in experimental diabetes, Indian J. Med. Res, 131 (2010) 820.

39) Kumar A, Ilavarasan R, Jayachandran $T$, Deecaraman M, Aravindhan P, Padmanabhan M, \& Krishnan M R V, Anti-diabetic activity of Syzygium cumini and its isolated compound against streptozotocin-induced diabetic rats, J. Med. Plant Res, 2 (2008) 246.

40) Renuka C, Anti diabetic effect of Biophytum sensitivum on alloxaninduced diabetic albino rats, J. Ecobiol, 24 (2009) 231.

41) Kumar S, Kumar D, Deshmuk R R, Lok Hande P D, More S N \& Ragari V D, Antidiabetic potential of Phyllanthus reticulatus in alloxan-induced diabetic mice, Fitoterapia, 79 (2008) 21.

42) Sedaghat R, Roghani M, Ahmadi M \& Ahmadi F, Antihyperglycemic and antihyperlipidemic effect of Rumex patientia seed preparation in streptozotocin-diabetic rats, J. Pathophys, 667 (2010) 1 .

43) Gokce G \& Haznedaroglu M Z, Evaluation of antidiabetic, antioxidant and vasoprotective effects of Posidonia oceanica extract, J. Ethnopharmacol, 115 (2008) 122.

44) Karimulla S K \& Kumar B P, Antidiabetic and antihyperlipidemic activity of bark of Bruguiera gymnorrhiza on streptozotocin induced diabetic rats, AJPST, 1 (2011) 4.

45) Karunanayake, E.H., Welihinda, J., Sirimanne, S.R., and Sinnadorai, G.: Oral hypoglycemic activity of some medicinal plants of Sri Lanka. J. Ethnopharmacol., 11, 223-231,1984.

46) Yadav J P, Saini S, Kalia A N \& Dangi A S, Hypoglycemic and hypolipidemic activity of ethanolic extract of Salvadora oleoides in normal and alloxan-induced diabetic rats, Indian $\mathrm{J}$ Pharmacol, 40 (2008) 23.

47) Zheng $X$, Li Y, Zhang L, Feng W \& Zhang X, Antihyperglycemic activity of Selaginella tamariscina (Beauv.) Spring, J Ethnopharmacol, 133 (2011) 531. 
48) Poongothai K, Ponmurugan P, Ahmed K S Z, Kumar S B \& Sheriff S A, Antihyperglycemic and antioxidant effects of Solanum xanthocarpum leaves (field grown \& in vitro raised) extracts on alloxan induced diabetic rats, Asian Pac. J. Trop. Med, 4 (2011) 778.

49) Alonso-Castro A J \& Salazar-Olivo L A, The anti-diabetic properties of Guazuma ulmifolia Lam are mediated by the stimulation of glucose uptake in normal and diabetic adipocytes without inducing adipogenesis, J. Ethnopharmacol, 118 (2008) 252.

50) Manikandan R Sundaram R, Srinivasan P, Beulaja $\mathrm{S} \&$ Arulvasu $\mathrm{C}$, Isolation of 1, 2 disubstituted idopyranose from Vitex negundo and its effects on diabetic rats, Int. J. Pharm. Anal, 1 (2009) 4.

51) Wadood, A., Wadood, N., and Shah, S.A.: Effects of Acacia arabica and Caralluma edulis on blood glucose levels on normal and alloxan diabetic rabbits. J. Pakistan Med. Assoc., 39, 208-212, 1989.

52) Aderibigbe, A.O., Emudianughe, T.S., and Lawal, B.A.: Antihyperglycemic effect of Mangifera indica in rat. Phytother Res., 13, 504-507, 1999.

53) R. C. Jain and C. R. Vyas, "Garlic in alloxan induced diabetic rabbits," American Journal of Clinical Nutrition, vol. 28, no. 7, pp. 684-685, 1975.

54) H. R.Madkor, S. W. Mansour, and G. Ramadan, "Modulatory effects of garlic, ginger, turmeric and their mixture on hyperglycaemia, dyslipidaemia and oxidative stress in streptozotocinnicotinamide diabetic rats," British Journal of Nutrition, vol. 105, no. 8, pp. 1210-1217, 2011.

55) M. J. Aybar, A. N. S'anchez Riera, A. Grau, and S. S. S'anchez, "Hypoglycemic effect of the water extract of Smallantus sonchifolius (yacon) leaves in normal and diabetic rats," Journal of Ethnopharmacology, vol. 74, no. 2, pp. 125-132, 2001.

56) Acherekar, S., Kaklij, G.S, Pote, M.S., and Kelkar, S.M.: Hypoglycemic activity of Eugenia jambolana and ficus bengalensis: mechanism of action. In vivo, 5, 143-147, 1991.

57) Patil, A., et al., (2012).Antidiabetic effect of polyherbal combinations in STRAPTOZOCIN induced diabetes involve inhibition of $\alpha$-amylase and $\alpha$-glucosidase with amelioration of lipid profile. Phytopharmacology, 2(1),46-57.

58) Pandhare, R.B., et al., (2012). Antihyperglycaemic and lipid lowering potential of
Adenanthera pavonina Linn. in streptozotocin induced diabetic rats. Oriental Pharmacy and Experimental Medicine, 12(3), 197-203.

59) Park, E.Y., et al., (2012). Increase in Insulin Secretion Induced by Panax ginseng Berry Extracts Contributes to the Amelioration of Hyperglycemia in Streptozotocin induced Diabetic Mice. J Ginseng Res, 36(2), 153-60.

60) Kumavat, U.C., S.N. Shimpi, and S.P. Jagdale. (2012). Hypoglycemic activity of Cassia javanica Linn. in normal and streptozotocin-induced diabetic rats. Journal of advanced pharmaceutical technology \& research, 3(1), 47.

61) Muralikrishnan, G., S.K. Pillai, and F. Shakeel. (2012). Protective effects of Ocimum sanctum on lipid peroxidation and antioxidant status in streptozocin-induced diabetic rats. Natural product research, 26(5), 474-478.

62) Owo, D.U., et al., (2012). Oral administration of aqueous leaf extract of ocimum gratissimum ameliorates polyphagia, polydipsia and weight loss in streptozotocin-induced diabetic rats. American Journal of Medicine and Medical Sciences, 2(3), 45-49.

63) P., R.B., et al., (2012). Hypoglycemic Activity of Methanolic Extract of Talinum Triagulare Leaves in Normal and Streptozotocin Induced Diabetic Rats. Journal of Applied Pharmaceutical Science, 2(5), 197-201. 